\title{
Allometric Equations for Estimating Tree Aboveground Biomass in Tropical Dipterocarp Forests of Vietnam
}

\author{
Bao Huy ${ }^{1,2}$, Krishna P. Poudel ${ }^{2}$, Karin Kralicek ${ }^{2}$, Nguyen Dinh Hung $^{3}$, Phung Van Khoa ${ }^{4}$, \\ Vu Tan Phương ${ }^{5}$ and Hailemariam Temesgen ${ }^{2, *}$ \\ 1 Department of Forest Resources and Environment Management, Tay Nguyen University, 567 Le Duan, \\ Buon Ma Thuot, Dak Lak 630000, Vietnam; baohuy.frem@gmail.com \\ 2 Department of Forest Engineering, Resources and Management, Oregon State University, Corvallis, \\ OR 97333, USA; krishna.poudel@oregonstate.edu (K.P.P.); karin.kralicek@gmail.com (K.K.) \\ 3 Forest Inventory and Planning Institute, Vinh Quynh, Thanh Tri, Ha Noi 100000, Vietnam; \\ dinhhung28@yahoo.com \\ 4 Vietnam National University of Forestry, Xuan Mai, Chuong My, Ha Noi 100000, Vietnam; \\ khoaduongfuvcsu@gmail.com \\ 5 Vietnamese Academy of Forest Sciences, Đuc Thang, Bac Tu Liem, Ha Noi 100000, Vietnam; \\ phuong.vt@vafs.gov.vn \\ * Correspondence: hailemariam.temesgen@oregonstate.edu; Tel.: +1-541-7378549; Fax: +1-541-7379126 \\ Academic Editors: Shibu Jose and Timothy A. Martin \\ Received: 23 May 2016; Accepted: 16 August 2016; Published: 22 August 2016
}

\begin{abstract}
There are few allometric equations available for dipterocarp forests, despite the fact that this forest type covers extensive areas in tropical Southeast Asia. This study aims to develop a set of equations to estimate tree aboveground biomass (AGB) in dipterocarp forests in Vietnam and to validate and compare their predictive performance with allometric equations used for dipterocarps in Indonesia and pantropical areas. Diameter at breast height (DBH), total tree height $(\mathrm{H})$, and wood density (WD) were used as input variables of the nonlinear weighted least square models. Akaike information criterion (AIC) and residual plots were used to select the best models; while percent bias, root mean square percentage error, and mean absolute percent error were used to compare their performance to published models. For mixed-species, the best equation was $\mathrm{AGB}=0.06203 \times \mathrm{DBH}^{2.26430} \times \mathrm{H}^{0.51415} \times \mathrm{WD}^{0.79456}$. When applied to a random independent validation dataset, the predicted values from the generic equations and the dipterocarp equations in Indonesia overestimated the AGB for different sites, indicating the need for region-specific equations. At the genus level, the selected equations were $\mathrm{AGB}=0.03713 \times \mathrm{DBH}^{2.73813}$ and $\mathrm{AGB}=0.07483 \times \mathrm{DBH}^{2.54496}$ for two genera, Dipterocarpus and Shorea, respectively, in Vietnam. Compared to the mixed-species equations, the genus-specific equations improved the accuracy of the AGB estimates. Additionally, the genus-specific equations showed no significant differences in predictive performance in different regions (e.g., Indonesia, Vietnam) of Southeast Asia.
\end{abstract}

Keywords: aboveground biomass; allometric equation; dipterocarp forest; genus; Southeast Asia

\section{Introduction}

There is a significant need globally and in Vietnam to develop equations that estimate forest biomass and carbon for national measuring, reporting, and verification systems. Under the United Nations Framework Convention on Climate Change, countries must report the state of their forest resources through initiatives such as the United Nations collaborative programme on Reducing Emissions from Deforestation and Forest Degradation Plus UN-REDD+ programme [1] in developing 
countries [2]. For high accuracy, equations specific to dominant forest types and ecological regions are necessary.

Dipterocarpaceae is one of the most well-known tree families in the tropics for its species' iconic form and value as timber [3]. Timber species of Dipterocarpaceae are distributed widely throughout tropical Asia, spanning multiple climatic zones and geographic regions [4]. In Vietnam, this forest type covers approximately 650,000 ha and is distributed in two main ecological regions or ecoregions, namely the Central Highlands (CH) and the Southeast (SE) [5]. Differences in historical management of dipterocarps have resulted in an uneven balance of knowledge across their range, with much known about dipterocarps on the Indian subcontinent and comparatively little known about the dipterocarps of Southeast Asia [3]. In Vietnam, the ability to accurately estimate biomass and carbon in dipterocarp forests is complicated further by the mixed-species nature of this forest type [4].

Jenkins et al. [6,7] performed a modified national-level meta-analysis of allometric regression equations for total aboveground biomass (AGB) based on tree diameter and developed consistent equations for tree species in the United States using a logarithm function as the general form of these equations. Power models relating tree AGB to diameter at breast height (DBH) or more complex associations of input variables have also been widely developed and used for pantropic $[8,9]$. For example, Ter-Mikaelian and Korzukhin [10] used power models to estimate biomass for 65 North American tree species. In general, numerous publications suggest power models as a suitable option for building allometric equations based on one or more variables [8,11]. In developing biomass equations for pantropic or dipterocarp forests in the Southeast Asia, Brown [12], and Basuki et al. [13] applied logarithmic transformation of the power model. Picard et al. [14] pointed out that although being a good model for biomass prediction, the power model was outperformed by the allometric model.

The literature on allometric equations developed to estimate biomass for tropical forests is sizable [12,13,15-21]. However, there is limited literature and allometric equations for tropical dipterocarp forests [13] despite covering extensive areas in tropical Southeast Asia. To date, there are only a few general pantropical equations, but due to the range of diverse forest types with different characteristics in this region, there is a need to develop more specific biomass equations. Using data collected from 122 destructively sampled trees, Basuki et al. [13] developed allometric equations for dipterocarp forests, including one for each of the four main genera (Dipterocarpus, Hopea, Polaquium, and Shorea), one for commercial forests, and one for mixed-species of dipterocarps in East Kalimantan, Indonesia. The input variables of these equations were DBH, wood density (WD), and commercial bole height. Despite the development of equations for the main genera of the dipterocarp forest type, these authors focused on only one model form: a power model linearized by log transformation. Furthermore, they did not compare the predictive performances of genus or mixed-species allometric equations.

In Vietnam, there were a few allometric equations developed before the beginning of the UN-REDD programme [8,9]. Recently, Huy et al. [22] developed aboveground biomass equations for the evergreen broadleaf forests of the South Central Coastal ecoregion. The authors of this study report on the development of national-scale allometric equations to estimate tree biomass for the dipterocarp forest type in Vietnam, which was summarized and introduced by Sola et al. [8,9]. The objectives of this study were to: (i) develop equations to estimate AGB of dipterocarp forests in Vietnam; (ii) examine the performance of nonlinear mixed models using ecoregion as a random effect and develop separate equations for both mixed-species and dominant genera; and (iii) validate the accuracy of selected equations and compare them with both allometric equations for dipterocarps in Indonesia [13] and general pantropic equations $[12,16,17,19]$.

\section{Materials and Methods}

\subsection{Study Sites}

The data for this study were collected in two of the eight agro-ecological zones or ecoregions of Vietnam [5,8]: $\mathrm{CH}$ and SE. (Binh Thuan Province). The ecoregion classification accounts for 
environmental variability with respect to climate, soil, and altitude, and is therefore relevant to forest stratification. Most of the country's dipterocarp forests exist within the $\mathrm{CH}$ and SE ecoregions. Figure 1 shows the location of sample plots of dipterocarps of two agro-ecological zones.

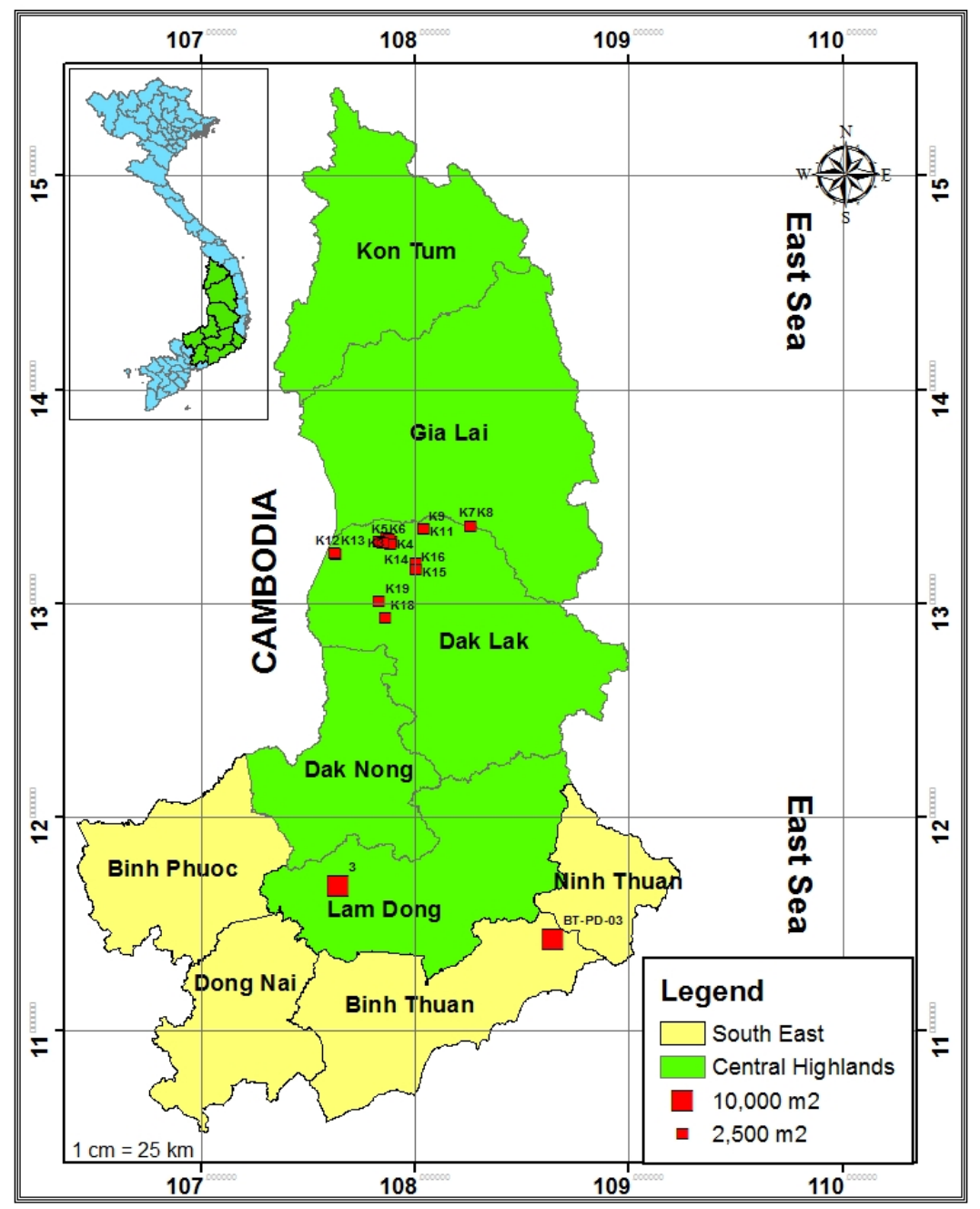

Figure 1. The location of sample plots in two ecoregions where the dipterocarp forests of Vietnam are distributed.

The $\mathrm{CH}$ has an area of approximately 600,000 ha of the dipterocarp forest located at an elevation of 197 to $417 \mathrm{~m}$ with less than $10^{\circ}$ slope. Mean annual rainfall is $1600 \mathrm{~mm}$ with a dry season lasting four months and mean annual temperature of $25.3^{\circ} \mathrm{C}$ [23]. The SE ecoregion has an area of approximately 50,000 ha of the dipterocarp forest located at an elevation of $230 \mathrm{~m}$ with less than $3^{\circ}$ slope. Mean annual rainfall for this ecoregion is $1003 \mathrm{~mm}$ with a dry season lasting three months and mean annual temperature of $25.5^{\circ} \mathrm{C}$ [23]. Both ecoregions have a mixed-dipterocarp forest that is distributed primarily on a soil type of igneous rocks [24] with stand density ranging from 256 to 1292 trees ha $^{-1}$ and basal area ranging from 10 to $25 \mathrm{~m}^{2} \mathrm{ha}^{-1}$.

\subsection{Sampling Design and Data Collection}

Forest inventory data for the $\mathrm{CH}$ and SE ecoregions was collected with the support of Vietnam UN-REDD+ Phase I Program. Most of the data for the $\mathrm{CH}$ ecoregion was collected by the main author of this study (Huy et al. [25]) with the support of the Vietnam Ministry of Education and Training. Thirteen 0.25 ha $(50 \mathrm{~m} \times 50 \mathrm{~m})$ plots from the $\mathrm{CH}$, home of the dipterocarp forests in Vietnam, and one 
1 ha plot from the SE ecoregion were surveyed. Attributes measured were plot location, forest status, basal area, slope, soil type, and standing tree measurements: species, DBH $(\mathrm{cm})$, and tree height $(\mathrm{H}, \mathrm{m})$ of all trees with $\mathrm{DBH} \geq 5 \mathrm{~cm}$. Within the sample plots, the selection of sample trees was proportional to the number of trees in each of the $10 \mathrm{~cm}$ DBH class. The DBH of sample trees ranged from 5 to $50 \mathrm{~cm}$ and heights ranged from 2 to $24 \mathrm{~m}$. A complete list of the species, families, and genera of the sample trees used in modeling is provided in Table 1. A total of 222 trees were destructively sampled for data collection between the $\mathrm{CH}$ (168 trees, 10-15 trees per 0.25-ha plot) and SE (54 trees) ecoregion.

Table 1. Number of destructively sampled trees $(N)$, average WD and standard deviation (SD) of WD

by family, genus, and species. Family and genus-level averages are in bold.

\begin{tabular}{|c|c|c|c|}
\hline Family/Genus/Species & $N$ & Average WD $\left(\mathrm{g} / \mathrm{cm}^{3}\right)$ & SD of WD $\left(\mathrm{g} / \mathrm{cm}^{3}\right)$ \\
\hline Chrysobalanaceae & 3 & 0.535665 & 0.016343 \\
\hline Parinari & 3 & 0.535665 & 0.016343 \\
\hline Parinari anamensis Hance & 3 & 0.535665 & 0.016343 \\
\hline Combretaceae & 23 & 0.747057 & 0.094749 \\
\hline Terminalia & 23 & 0.747057 & 0.094749 \\
\hline Terminalia alata Roth & 16 & 0.730093 & 0.100805 \\
\hline Terminalia corticosa Pierre ex Laness & 7 & 0.785830 & 0.070653 \\
\hline Dilleniaceae & 2 & 0.700423 & 0.246027 \\
\hline Dillenia & 2 & 0.700423 & 0.246027 \\
\hline Dillenia sp. & 2 & 0.700423 & 0.246027 \\
\hline Dipterocarpaceae & 130 & 0.657599 & 0.098560 \\
\hline Dipterocarpus & 94 & 0.627294 & 0.080587 \\
\hline Dipterocarpus intricatus Dyer & 21 & 0.589667 & 0.037682 \\
\hline Dipterocarpus obtusifolius Teijsm. ex Miq. & 10 & 0.640704 & 0.050715 \\
\hline Dipterocarpus tuberculatus Roxb. & 63 & 0.637707 & 0.091056 \\
\hline Shorea & 36 & 0.736729 & 0.098185 \\
\hline Shorea obtusa Wall. ex Blume & 28 & 0.772400 & 0.074928 \\
\hline Shorea siamensis Miq. & 8 & 0.611881 & 0.060359 \\
\hline Phyllanthaceae & 7 & 0.612478 & 0.074246 \\
\hline Aporosa & 7 & 0.612478 & 0.074246 \\
\hline Aporosa sp. & 7 & 0.612478 & 0.074246 \\
\hline Hypericaceae & 1 & 0.625000 & - \\
\hline Cratoxylum & 1 & 0.625000 & - \\
\hline \multicolumn{4}{|l|}{ Cratoxylum formosum (Jacq.) Benth. \& Hook.f. ex } \\
\hline Dyer & 1 & 0.625000 & - \\
\hline Irvingiaceae & 6 & 0.704833 & 0.017702 \\
\hline Irvingia & 6 & 0.704833 & 0.017702 \\
\hline Irvingia malayana Oliv. ex A.W.Benn. & 6 & 0.704833 & 0.017702 \\
\hline Lauraceae & 2 & 0.585500 & 0.024749 \\
\hline Cryptocarya & 2 & 0.585500 & 0.024749 \\
\hline Cryptocarya sp. & 2 & 0.585500 & 0.024749 \\
\hline Lecythidaceae & 5 & 0.592586 & 0.134872 \\
\hline Careya & 5 & 0.592586 & 0.134872 \\
\hline Careya arborea Roxb. & 5 & 0.592586 & 0.134872 \\
\hline Leguminosae & 19 & 0.683648 & 0.082150 \\
\hline Dalbergia & 4 & 0.606063 & 0.049240 \\
\hline Dalbergia cochinchinensis Pierre & 3 & 0.587667 & 0.040079 \\
\hline Dalbergia nigrescens var. saigonensis (Pierre) Gagnep. & 1 & 0.661252 & - \\
\hline Sindora & 1 & 0.818989 & - \\
\hline Sindora siamensis Miq. & 1 & 0.818989 & - \\
\hline Xylia & 14 & 0.696148 & 0.073180 \\
\hline Xylia xylocarpa (Roxb.) Taub. & 14 & 0.696148 & 0.073180 \\
\hline Loganiaceae & 2 & 0.600613 & 0.006983 \\
\hline Strychnos & 2 & 0.600613 & 0.006983 \\
\hline Strychnos nux-blanda A.W. Hill & 2 & 0.600613 & 0.006983 \\
\hline Myrtaceae & 6 & 0.521244 & 0.062018 \\
\hline Syzygium & 6 & 0.521244 & 0.062018 \\
\hline
\end{tabular}


Table 1. Cont.

\begin{tabular}{|c|c|c|c|}
\hline Family/Genus/Species & $N$ & Average WD $\left(\mathrm{g} / \mathrm{cm}^{3}\right)$ & SD of WD $\left(\mathrm{g} / \mathrm{cm}^{3}\right)$ \\
\hline Syzygium cumini (L.) Skeels & 2 & 0.589732 & 0.062332 \\
\hline Syzygium sp. & 4 & 0.487000 & 0.020607 \\
\hline Rubiaceae & 15 & 0.589079 & 0.051010 \\
\hline Adina & 2 & 0.571000 & 0.000000 \\
\hline Adina pilulifera (Lam.) Franch. ex Drake & 2 & 0.571000 & 0.000000 \\
\hline Haldina & 2 & 0.611293 & 0.031190 \\
\hline Haldina cordifolia (Roxb.) Ridsdale & 2 & 0.611293 & 0.031190 \\
\hline Morinda & 1 & 0.463000 & - \\
\hline Morinda citrifolia L. & 1 & 0.463000 & - \\
\hline Nauclea & 10 & 0.600860 & 0.042858 \\
\hline Nauclea orientalis (L.) L. & 10 & 0.600860 & 0.042858 \\
\hline Sapindaceae & 1 & 0.630000 & - \\
\hline Sapindus & 1 & 0.630000 & - \\
\hline Sapindus saponaria L. & 1 & 0.630000 & - \\
\hline Grand Total & 222 & 0.656475 & 0.101823 \\
\hline
\end{tabular}

Species name was recorded and $\mathrm{DBH}, \mathrm{H}$ were measured on sample trees prior to felling. Total tree height $(\mathrm{H})$ and green component mass for stems with bark, branches, and foliage was measured post felling. To establish the green-to-dry ratio of each tree, five samples for stem, three for branches, and two for old and new leaves were brought to the laboratory in sealed plastic bags to determine moisture content and reweighed to determine their mass in grams. Samples were then dried at $105{ }^{\circ} \mathrm{C}$ until a constant weight was reached $[13,21,26]$. The dry biomass of stem, branches, and leaves was estimated by multiplying the green biomass with the averaged green-to-dry ratio of each component. The total dry weight of a tree (AGB) was obtained by summing the dry biomass of the stem, branches, and foliage.

For wood density (WD) analysis, samples were taken from every one-fifth of the stem length. The water displacement method was used to measure the volume, and the averaged $W D\left(\mathrm{~g} / \mathrm{cm}^{3}\right)$ per sample tree was calculated as oven-dry weight divided by volume at saturation.

Table 2 shows a summary for each of the predictors and the response variables of the destructively sampled trees for mixed-species and two main genera: Dipterocarpus and Shorea.

Table 2. Summary for each of the predictors and the response variables of the destructively sampled trees for mixed-species and two main genera.

\begin{tabular}{llllll}
\hline Level & Summary & DBH $(\mathbf{c m})$ & H $(\mathbf{m})$ & WD $\left(\mathbf{g} / \mathbf{c m}^{\mathbf{3}}\right)$ & AGB $\mathbf{( k g )}$ \\
\hline \multirow{4}{*}{ Mixed-Species } & Min & 3.4 & 2.5 & 0.379 & 1.3 \\
& Average & 17.6 & 10.3 & 0.656 & 184.9 \\
& Max & 48.8 & 23.5 & 0.953 & 1710.8 \\
& Standard Deviation & 10.3 & 4.5 & 0.102 & 315.0 \\
& $n$ & 222 & 222 & 222 & 222 \\
\hline \multirow{5}{*}{ Dipterocarpus Genus } & Min & 4.9 & 3.8 & 0.379 & 1.5 \\
& Average & 20.4 & 11.2 & 0.627 & 285.6 \\
& Standard Deviation & 48.8 & 23.5 & 0.858 & 1710.8 \\
& $n$ & 94.4 & 5.3 & 0.081 & 431.8 \\
& Min & 5.6 & 94 & 94 & 94 \\
\hline \multirow{5}{*}{ Shorea Genus } & Average & 15.2 & 4.4 & 0.507 & 2.9 \\
& Max & 23.0 & 14.1 & 0.737 & 86.4 \\
& Standard Deviation & 4.2 & 2.4 & 0.917 & 205.9 \\
& $n$ & 36 & 36 & 36 & 52.5 \\
\hline
\end{tabular}




\subsection{Equation Development and Selection}

The dataset was randomly split 200 times into model development dataset (70\% or 156 trees) and validation dataset ( $30 \%$ or 66 trees). After selecting, validating, and comparing the equations, the final parameters of the selected equations were obtained using the entire dataset (222 trees).

Equations were developed at two levels: mixed-species (all trees) and dominant genera of the dipterocarps (Dipterocarpus and Shorea). Exploratory analysis of destructively sampled tree data by ecoregion, family, and genus suggested the use of a power model with random effects (Figure 2).
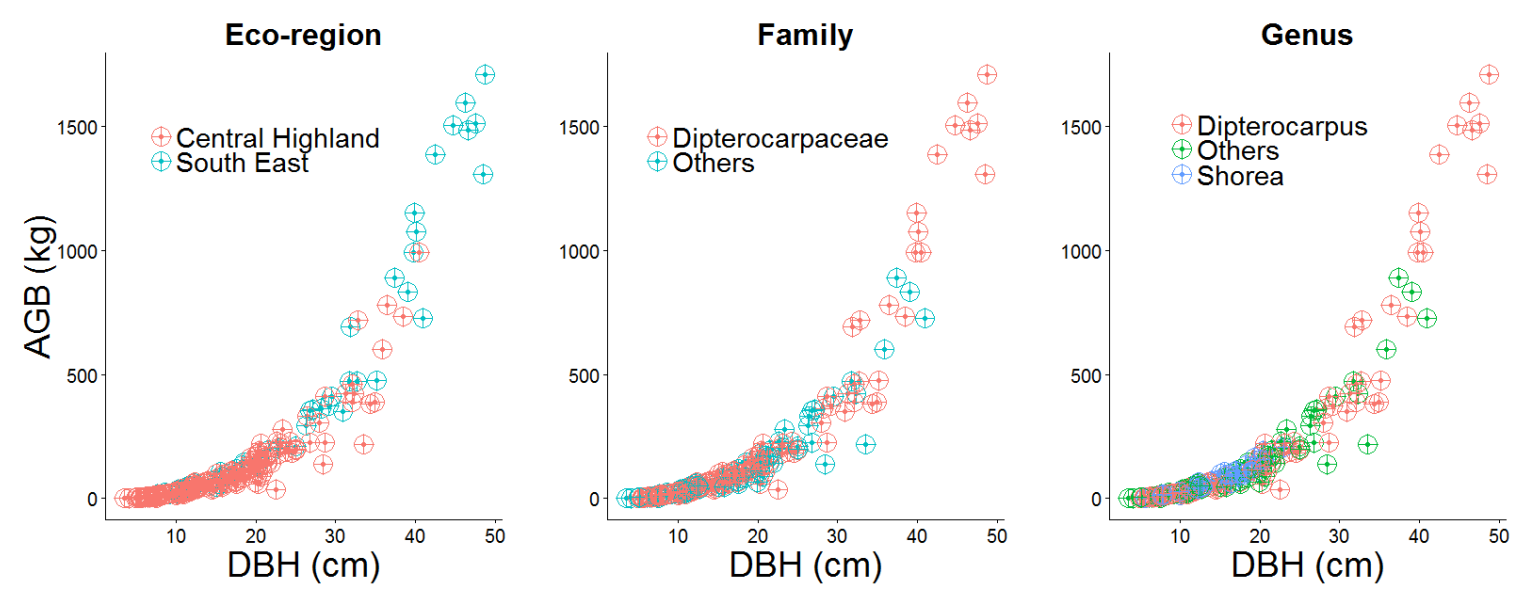

Figure 2. AGB vs. DBH of destructively sampled trees by ecoregion, plant family, and genus. The trend of relationship between AGB and DBH follows power model.

The nonlinear mixed-effects models used in this study had the following form:

$$
\begin{gathered}
Y_{i j}=\left(a_{o}+a_{i}\right) \times X_{i j}\left(b_{o}+b_{i}\right)+\varepsilon_{i j} \\
\varepsilon_{i j} \sim \operatorname{iid} \mathcal{N}\left(0, \sigma^{2}\right)
\end{gathered}
$$

where $Y_{i j}$ is the observed ABG $(\mathrm{kg})$ for the $j$ th tree associated with the $i$ th ecoregion; $a_{o}$ and $b_{o}$ are parameters of the model; $a_{i}$ and $b_{i}$ are parameters associated with the random effect of the $i$ th ecoregion; and $X_{i j}$ is the $\mathrm{DBH}(\mathrm{cm}), \mathrm{H}(\mathrm{m}), \mathrm{WD}\left(\mathrm{g} / \mathrm{cm}^{3}\right), \mathrm{DBH}^{2} \mathrm{H}\left(\mathrm{m}^{3}\right)$, or $\mathrm{DBH}^{2} \mathrm{HWD}(\mathrm{kg})$ for the $j$ th tree in $i$ th ecoregion; and $\varepsilon_{i j}$ is the random error associated with the $j$ th tree in $i$ th ecoregion. The input variables $\mathrm{DBH}^{2} \mathrm{H}$ and $\mathrm{DBH}^{2} \mathrm{HWD}$ for $X_{i j}$ are approximations of volume and $\mathrm{AGB}$, respectively, and were calculated as follows:

$$
\begin{gathered}
\mathrm{DBH}^{2} \mathrm{H}=\left(\frac{\mathrm{DBH}}{100}\right)^{2} \times \mathrm{H} \\
\mathrm{DBH}^{2} \mathrm{HWD}=\mathrm{DBH}^{2} \mathrm{H} \times \mathrm{WD} \times 1000
\end{gathered}
$$

Preliminary analysis also indicated that heterogeneous variance of residuals existed in all AGB models, as the variance tended to increase with increasing diameters. A power variance function as defined in Equation (5) was used to take into account the heterogeneity of residuals.

$$
\operatorname{Var}\left(\varepsilon_{i j}\right)=\sigma^{2}\left(X_{i j}\right)^{k}
$$

where $\sigma^{2}$ is the residual sum of squares, $X_{i j}$ is the weighting variable $\left(\mathrm{DBH}, \mathrm{DBH}^{2} \mathrm{H}\right.$, or $\mathrm{DBH}^{2} \mathrm{HWD}$ in this study), and $k$ is the variance function coefficient. The weighted nonlinear mixed-effects models with a specified variance function were fit using the NLME package [27] in R statistical software [28].

Allometric equations were first developed for mixed-species (all trees) and the best model forms for each input variable were selected. Best models were determined as those with significant 
parameters, no obvious issues with diagnostic plot, lower Akaike information criterion (AIC), and higher adjusted $R^{2}$. The random effect of ecoregion was then tested for significance. Finally, the equations were built for two dominant genera of dipterocarp forests, Dipterocarpus and Shorea.

\subsection{Equation Validation and Comparison}

Performance of selected equations were validated and compared to each other and to equations developed for the dipterocarp and pantropic forests in terms of percent bias, root mean square percentage error (RMSPE), and mean absolute percent error (MAPE) [29]. These indicators were calculated for the validation dataset and smaller values were preferred. The cross-validation statistics were computed for each realization of randomly selected data and averaged over the 200 realizations [30].

$$
\begin{gathered}
\text { Percent Bias }=\frac{100}{R} \sum_{r=1}^{R} \sum_{i=1}^{n_{r}}\left[\frac{y_{r i}-\hat{y}_{r i}}{y_{r i}}\right] / n_{r} \\
\text { RMSPE }=\frac{100}{R} \sum_{r=1}^{R} \sqrt{\sum_{i=1}^{n_{r}}\left(\frac{y_{r i}-\hat{y}_{r i}}{y_{r i}}\right)^{2} / n_{r}} \\
\text { MAPE }=\frac{100}{R} \sum_{r=1}^{R} \sum_{i=1}^{n_{r}}\left[\frac{\left|y_{r i}-\hat{y}_{r i}\right|}{y_{r i}}\right] / n_{r}
\end{gathered}
$$

where, $R$ is the number of realizations (200); $n_{r}$ is the number of trees per realization $r ; y_{r i}$ and $\hat{y}_{r i}$ are the observed and predicted AGB $(\mathrm{kg})$ for the $i$ th tree in realization $r$, respectively.

The validation dataset was used to evaluate the performance of the following allometric equations developed for pantropic and dipterocarp forests of Indonesia and compared with the selected equations for mixed-species and genera developed in this study:

Pan-tropic equations for mixed-species:

Brown (1997) [12]:

$$
\mathrm{AGB}=\exp (-2.134+2.530 \times \log (\mathrm{DBH}))
$$

IPCC (2003) [19]:

$$
\mathrm{AGB}=\exp \left(-2.289+2.649 \times \log (\mathrm{DBH})-0.021 \times(\log (\mathrm{DBH}))^{2}\right)
$$

Chave et al. (2005) [16] for dry forests:

$$
\mathrm{AGB}=\mathrm{WD} \times \exp \left(-0.667+1.784 \times \log (\mathrm{DBH})+0.207 \times(\log (\mathrm{DBH}))^{2}-0.0281 \times(\log (\mathrm{DBH}))^{3}\right)
$$

Chave et al. (2014) [17]:

$$
\mathrm{AGB}=0.0673 \times\left(\mathrm{WD} \times \mathrm{DBH}^{2} \times \mathrm{H}\right)^{0.976}
$$

Dipterocarp forest equations of Basuki et al. [13] for Indonesia:

Basuki et al. I (2009) for mixed-species:

$$
\mathrm{AGB}=\exp (-1.201+2.196 \times \log (\mathrm{DBH}))
$$

Basuki et al. II (2009) for mixed-species:

$$
\mathrm{AGB}=\exp (-0.744+2.188 \times \log (\mathrm{DBH})+0.832 \times \log (\mathrm{WD}))
$$

Basuki et al. I (2009) for Dipterocarpus genus: 


$$
\mathrm{AGB}=\exp (-1.232+2.178 \times \log (\mathrm{DBH}))
$$

Basuki et al. I (2009) for Shorea genus:

$$
\mathrm{AGB}=\exp (-2.193+2.371 \times \log (\mathrm{DBH}))
$$

where, $\log (\cdot)$ is natural logarithm and all other variables are as previously defined.

Finally, after selecting, validating, and comparing the equations with the pantropic and dipterocarp equations in Indonesia, the parameters of the selected equations in this study were obtained using the entire dataset (222 trees).

\section{Results}

Sizable differences were observed in WD among tree species, genus, and family. Average and standard deviation of WD for each plant species, genus, and family are presented in Table 1 and Figure 3.

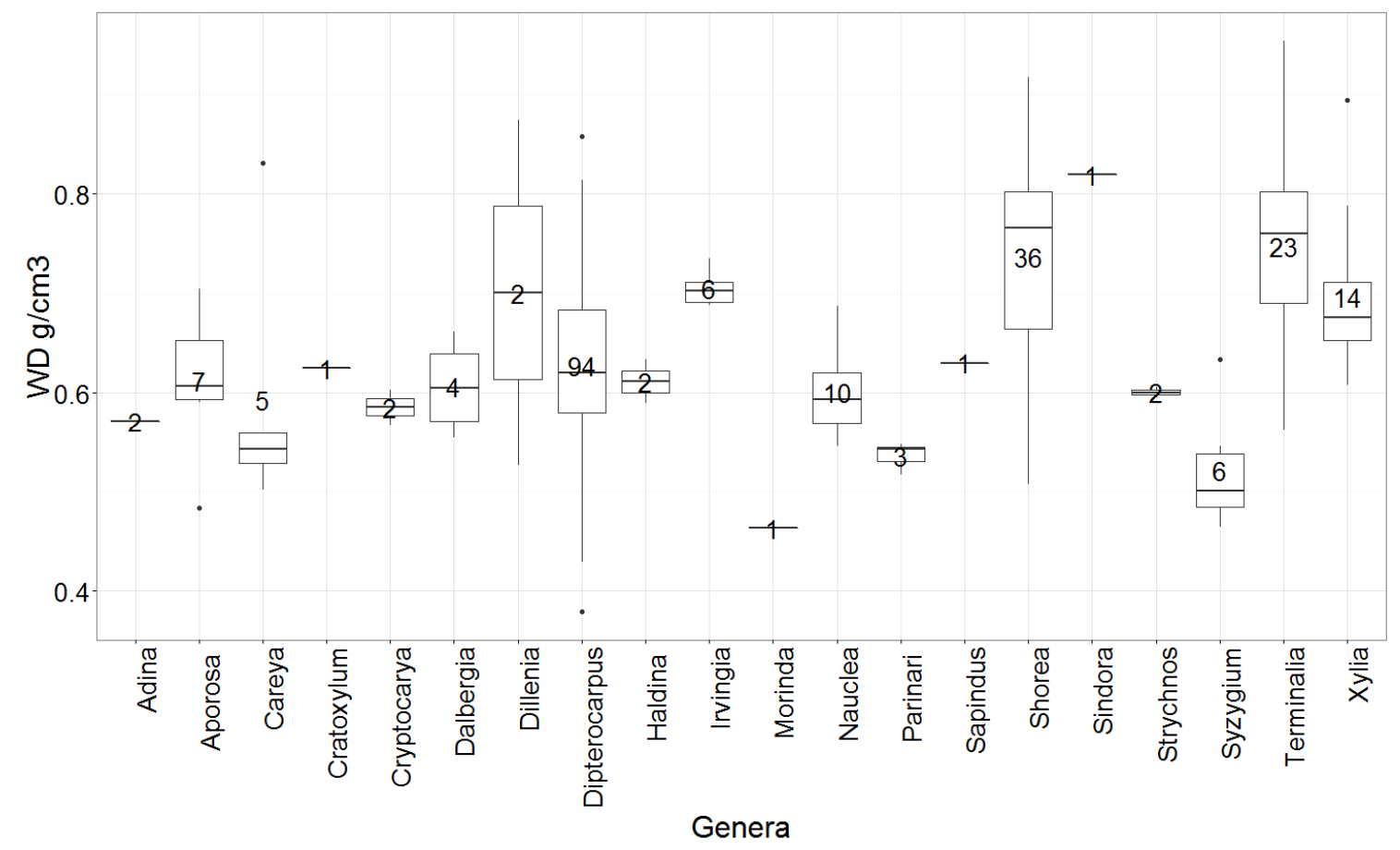

Figure 3. Box plot of WD by sampled genera in alphabetical order. Numbers inside the boxplots represent the sample size in that genus.

\subsection{Equations for Mixed-Species}

The summary of the model fit for fixed- and mixed-effects models using different covariates to describe AGB in mixed-species forests are given in Table 3. The adjusted $R^{2}$ of all models was more than 0.9 and the models that used separate input variables produced smaller AIC and RMSPE values compared to the models that used combined variables as the covariates. Therefore, equations with separate input variables were selected for mixed-species AGB estimation. Parameter estimates for these equations are presented in Table 4 and all parameters were statistically significant at the 0.001 level. Figure 4 shows the plots of fitted values and weighted residuals of those equations. The AIC value of the three-variable (DBH, $\mathrm{H}$, and WD) model with random effect of ecoregion was smaller compared to the same model without random effect. However, there was no substantial changes in 
the parameter estimates for different ecoregions. Therefore, we selected the fixed-effects model as our final model.

Table 3. Comparison of different AGB models for mixed-species with and without the random effect of ecoregion (156 trees).

\begin{tabular}{|c|c|c|c|c|c|c|}
\hline Model Selected & Model Form & Random Effect & Weight Variable & AIC & Adj. $R^{2}$ & RMSPE \\
\hline \multirow{3}{*}{ M1 } & Covariate: DBH & & & & & \\
\hline & $\mathrm{AGB}=a \times \mathrm{DBH}^{b}$ & None & $1 / \mathrm{DBH}^{k}$ & 1335 & 0.966 & 59.0 \\
\hline & $\mathrm{AGB}=a \times \mathrm{DBH}^{b}$ & Ecoregion & $1 / \mathrm{DBH}^{k}$ & 1335 & 0.966 & 59.0 \\
\hline \multirow{4}{*}{ M2 } & Covariates: DBH and $\mathrm{H}$ & & & & & \\
\hline & $\mathrm{AGB}=a \times\left(\mathrm{DBH}^{2} \mathrm{H}\right)^{b}$ & None & $1 /\left(\mathrm{DBH}^{2} \mathrm{H}\right)^{k}$ & 1374 & 0.967 & 48.1 \\
\hline & $\mathrm{AGB}=a \times \mathrm{DBH}^{b} \times \mathrm{H}^{c}$ & None & $1 / \mathrm{DBH}^{k}$ & 1324 & 0.975 & 51.1 \\
\hline & $\mathrm{AGB}=a \times \mathrm{DBH}^{b} \times \mathrm{H}^{c}$ & Ecoregion & $1 / \mathrm{DBH}^{k}$ & 1324 & 0.975 & 51.1 \\
\hline \multirow{4}{*}{ M3 } & Covariates: DBH and WD & & & & & \\
\hline & $\mathrm{AGB}=a \times\left(\mathrm{DBH}^{2} \mathrm{WD}\right)^{b}$ & None & $1 /\left(\mathrm{DBH}^{2} \mathrm{WD}\right)^{k}$ & 1337 & 0.901 & 53.7 \\
\hline & $\mathrm{AGB}=a \times \mathrm{DBH}^{b} \times \mathrm{WD}^{c}$ & None & $1 / \mathrm{DBH}^{k}$ & 1322 & 0.933 & 54.8 \\
\hline & $\mathrm{AGB}=a \times \mathrm{DBH}^{b} \times \mathrm{WD}^{c}$ & Ecoregion & $1 / \mathrm{DBH}^{k}$ & 1322 & 0.933 & 54.8 \\
\hline \multirow{4}{*}{ M4 } & Covariates: $\mathrm{DBH}, \mathrm{H}$, and WD & & & & & \\
\hline & $\mathrm{AGB}=a \times\left(\mathrm{DBH}^{2} \mathrm{HWD}\right)^{b}$ & None & $1 /\left(\mathrm{DBH}^{2} \mathrm{HWD}\right)^{k}$ & 1323 & 0.945 & 39.3 \\
\hline & $\mathrm{AGB}=a \times \mathrm{DBH}^{b} \times \mathrm{H}^{c} \times \mathrm{WD}^{d}$ & None & $1 / \mathrm{DBH}^{k}$ & 1298 & 0.940 & 43.7 \\
\hline & $\mathrm{AGB}=a \times \mathrm{DBH}^{b} \times \mathrm{H}^{c} \times \mathrm{WD}^{d}$ & Ecoregion & $1 / \mathrm{DBH}^{k}$ & 1280 & 0.940 & 43.7 \\
\hline
\end{tabular}

$k$ is the variance function coefficient.

Table 4. Selected AGB models with different input variables, their parameter estimates, and standard errors for mixed-species of the dipterocarp forests (based on the entire dataset, 222 trees).

\begin{tabular}{|c|c|c|c|c|c|}
\hline Model Selected & Covariate (s) & Model Form & & er Estimates & Standard Error \\
\hline M1 & $\mathrm{DBH}$ & $\mathrm{AGB}=a \times \mathrm{DBH}^{b}$ & $\begin{array}{l}a \\
b\end{array}$ & $\begin{array}{l}0.04742 \\
2.66663\end{array}$ & $\begin{array}{l}0.00434 \\
0.03151\end{array}$ \\
\hline M2 & $\mathrm{DBH}, \mathrm{H}$ & $\mathrm{AGB}=a \times \mathrm{DBH}^{b} \times \mathrm{H}^{c}$ & $\begin{array}{l}a \\
b \\
c\end{array}$ & $\begin{array}{l}0.03844 \\
2.40756 \\
0.40408\end{array}$ & $\begin{array}{l}0.00377 \\
0.05861 \\
0.07988\end{array}$ \\
\hline M3 & DBH, WD & $\mathrm{AGB}=a \times \mathrm{DBH}^{b} \times \mathrm{WD}^{c}$ & $\begin{array}{l}a \\
b \\
c\end{array}$ & $\begin{array}{l}0.07126 \\
2.60940 \\
0.59275\end{array}$ & $\begin{array}{l}0.00843 \\
0.03290 \\
0.59275\end{array}$ \\
\hline M4 & DBH, H, WD & $\mathrm{AGB}=a \times \mathrm{DBH}^{b} \times \mathrm{H}^{c} \times \mathrm{WD}^{d}$ & $\begin{array}{l}a \\
b \\
c \\
d\end{array}$ & $\begin{array}{l}0.06203 \\
2.26430 \\
0.51415 \\
0.79456\end{array}$ & $\begin{array}{l}0.00679 \\
0.05754 \\
0.07497 \\
0.11420\end{array}$ \\
\hline
\end{tabular}

The effect of ecoregion was then tested on the selected mixed-species models. The inclusion of ecoregion as a random effect did not improve the model fit (Table 3), nor did it change the parameter estimates substantially. After examining the between-ecoregion variability of the coefficient of the power equations, we found that there were no significant differences between the two ecoregions. Thus, the selected models with different input variables for mixed-species (equations in Table 4) can be applied to either $\mathrm{CH}$ or $\mathrm{SE}$ without considering the effect of different ecoregions. Among these models, the model with three input variables ( $\mathrm{DBH}, \mathrm{H}$, and WD) performed the best and had the following form:

$$
\mathrm{AGB}=0.06203 \times \mathrm{DBH}^{2.26430} \times \mathrm{H}^{0.51415} \times \mathrm{WD}^{0.79456}
$$



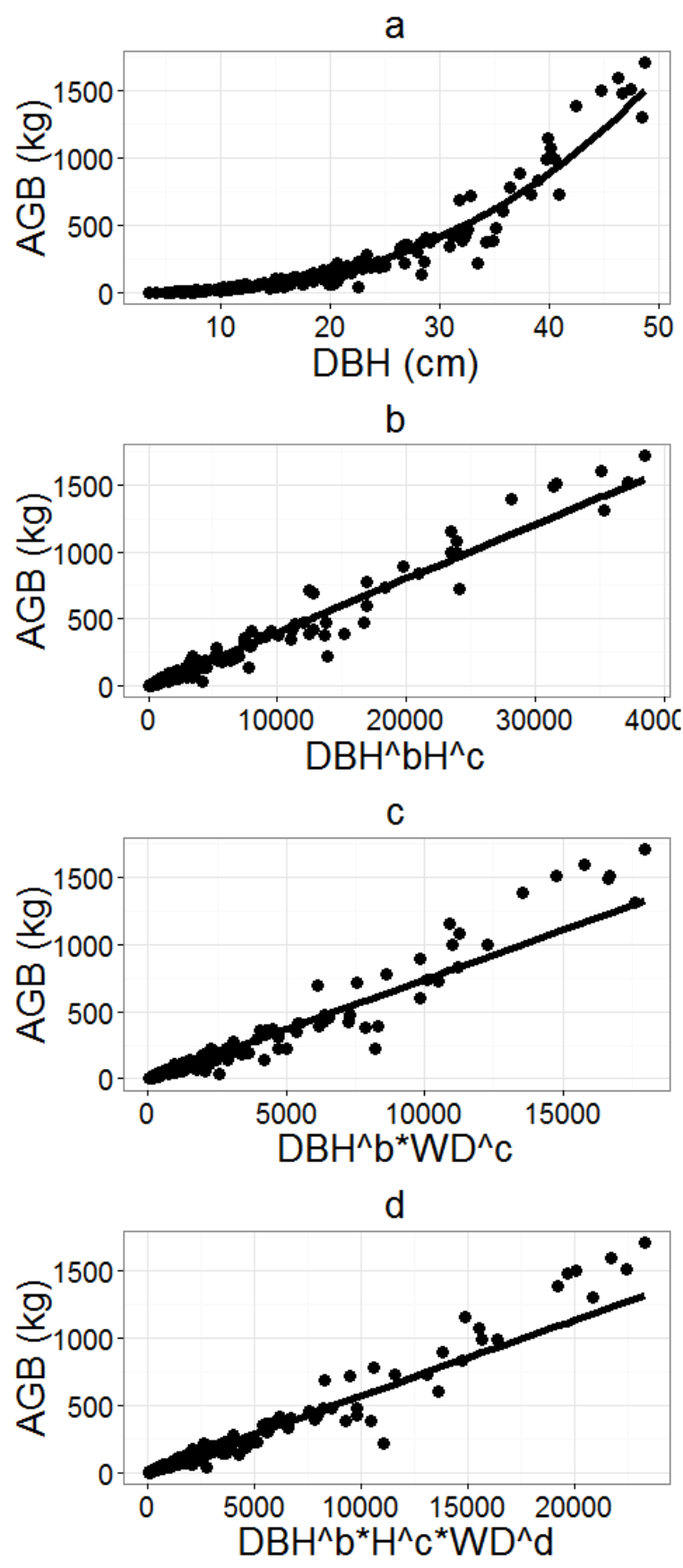
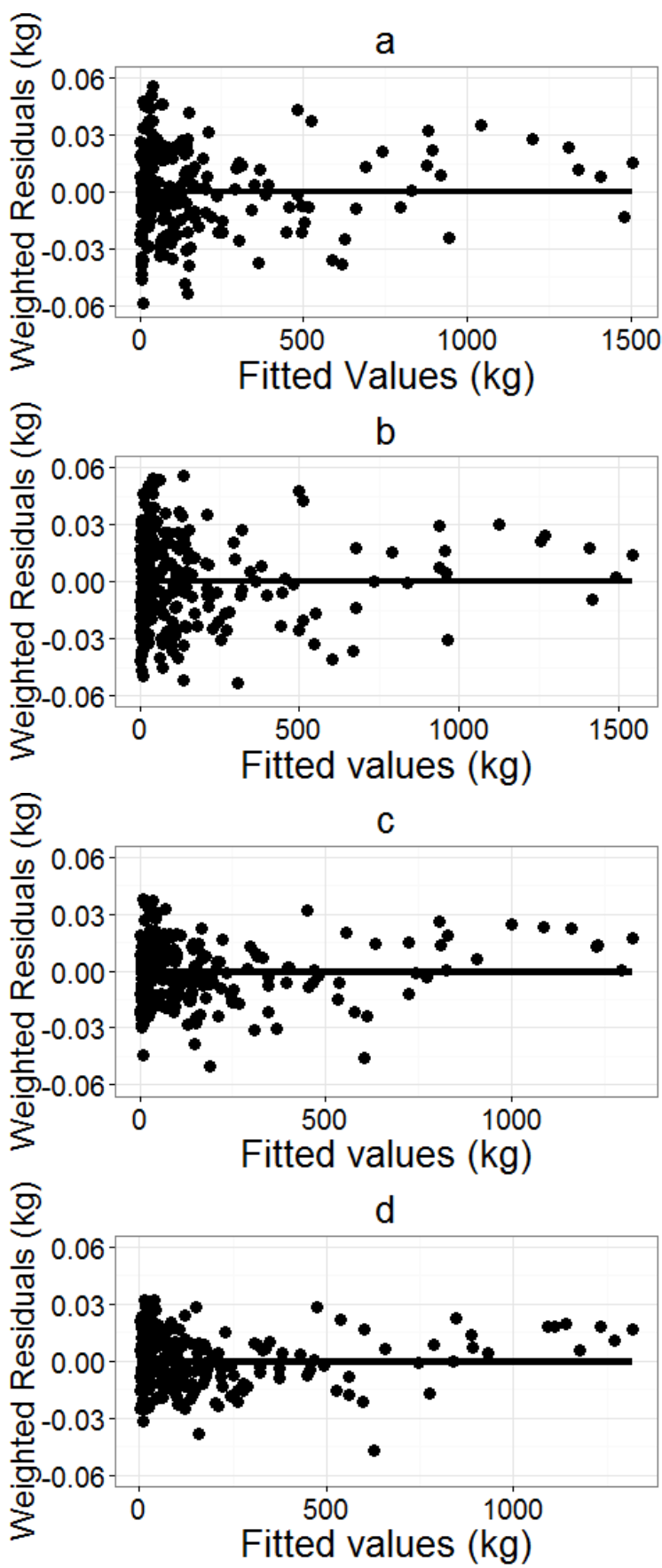

Figure 4. Plots of selected AGB models for mixed-species: fitted vs. observed (left column) and residuals vs. fitted (right column) using the entire dataset of 222 destructively sampled trees. (a) Model $\mathrm{AGB}=a \times \mathrm{DBH}^{b} ;(\mathbf{b})$ Model AGB $=a \times \mathrm{DBH}^{b} \times \mathrm{H}^{c} ;(\mathbf{c})$ Model AGB $=a \times \mathrm{DBH}^{b} \times \mathrm{H}^{c} \times \mathrm{WD}^{d}$.

\subsection{Equations for Dominant Genera}

The summary of the model fit for fixed-effects models using different covariates to describe AGB for these genera are given in Table 5. AIC and $R^{2}$ were very close between models for the same genus. Therefore, models with the fewest parameters were selected for parsimony and their parameter estimates are presented in Table 6. 
Table 5. Comparison of different AGB models with different input variables for Dipterocarpus (67 trees) and for Shorea (26 trees).

\begin{tabular}{|c|c|c|c|c|c|c|}
\hline Model Selected & Covariate(s) & Model Form & Weight Variable & AIC & Adj. $R^{2}$ & RMSPE \\
\hline & \multicolumn{6}{|c|}{ Genus: Dipterocarpus } \\
\hline D1 & $\mathrm{DBH}$ & $\mathrm{AGB}=a \times \mathrm{DBH}^{b}$ & $1 / \mathrm{DBH}^{k}$ & 600 & 0.970 & 60.7 \\
\hline \multirow[t]{2}{*}{ D2 } & \multirow{2}{*}{ DBH, H } & $\mathrm{AGB}=a \times\left(\mathrm{DBH}^{2} \mathrm{H}\right)^{b}$ & $1 / \mathrm{DBH}^{k}$ & 616 & 0.965 & 46.5 \\
\hline & & $\mathrm{AGB}=a \times \mathrm{DBH}^{b} \times \mathrm{H}^{\mathrm{c}}$ & $1 / \mathrm{DBH}^{k}$ & 600 & 0.979 & 54.1 \\
\hline \multirow[t]{2}{*}{ D3 } & \multirow{2}{*}{ DBH, WD } & $\mathrm{AGB}=a \times\left(\mathrm{DBH}^{2} \mathrm{WD}\right)^{b}$ & $1 /\left(\mathrm{DBH}^{2} \mathrm{WD}\right)^{k}$ & 603 & 0.920 & 61.8 \\
\hline & & $\mathrm{AGB}=a \times \mathrm{DBH}^{b} \times \mathrm{WD}^{c(\#)}$ & $1 / \mathrm{DBH}^{k}$ & 605 & 0.952 & 59.9 \\
\hline \multirow[t]{2}{*}{ D4 } & \multirow{2}{*}{$\mathrm{DBH}, \mathrm{H}, \mathrm{WD}$} & $\mathrm{AGB}=a \times\left(\mathrm{DBH}^{2} \mathrm{HWD}\right)^{b}$ & $1 /\left(\mathrm{DBH}^{2} \mathrm{HWD}\right)^{k}$ & 602 & 0.970 & 45.2 \\
\hline & & $\mathrm{AGB}=a \times \mathrm{DBH}^{b} \times \mathrm{H}^{c} \times \mathrm{WD}^{d}$ & $1 / \mathrm{DBH}^{k}$ & 601 & 0.970 & 49.8 \\
\hline \multirow{4}{*}{$\begin{array}{l}\text { S1 } \\
\text { S2 }\end{array}$} & \multicolumn{6}{|l|}{ Genus: Shorea } \\
\hline & DBH & $\mathrm{AGB}=a \times \mathrm{DBH}^{b}$ & $1 / \mathrm{DBH}^{k}$ & 220 & 0.919 & 25.4 \\
\hline & \multirow{2}{*}{$\mathrm{DBH}, \mathrm{H}$} & $\mathrm{AGB}=a \times\left(\mathrm{DBH}^{2} \mathrm{H}\right)^{b}$ & $1 /\left(\mathrm{DBH}^{2} \mathrm{H}\right)^{k}$ & 231 & 0.861 & 33.6 \\
\hline & & $\mathrm{AGB}=a \times \mathrm{DBH}^{b} \times \mathrm{H}^{c(\#)}$ & $1 / \mathrm{DBH}^{k}$ & 227 & 0.921 & 25.9 \\
\hline \multirow[t]{2}{*}{ S3 } & \multirow{2}{*}{ DBH, WD } & $\mathrm{AGB}=a \times\left(\mathrm{DBH}^{2} \mathrm{WD}\right)^{b}$ & $1 /\left(\mathrm{DBH}^{2} \mathrm{WD}\right)^{k}$ & 224 & 0.881 & 22.3 \\
\hline & & $\mathrm{AGB}=a \times \mathrm{DBH}^{b} \times \mathrm{WD}^{c(\#)}$ & $1 / \mathrm{DBH}^{k}$ & 226 & 0.912 & 22.6 \\
\hline \multirow[t]{2}{*}{ S4 } & \multirow{2}{*}{$\mathrm{DBH}, \mathrm{H}, \mathrm{WD}$} & $\mathrm{AGB}=a \times\left(\mathrm{DBH}^{2} \mathrm{HWD}\right)^{b}$ & $1 /\left(\mathrm{DBH}^{2} \mathrm{HWD}\right)^{k}$ & 220 & 0.894 & 24.0 \\
\hline & & $\mathrm{AGB}=a \times \mathrm{DBH}^{b} \times \mathrm{H}^{c(\#)} \times \mathrm{WD}^{d}$ & $1 / \mathrm{DBH}^{k}$ & 231 & 0.920 & 21.0 \\
\hline
\end{tabular}

${ }^{(\#)}: p$-value of the parameter $>0.05$ and $k$ is the variance function coefficient.

Table 6. Parameter estimates and their standard errors for the selected AGB models with different input variables for Dipterocarpus (the entire dataset, 94 trees) and for Shorea (the entire dataset, 36 trees).

\begin{tabular}{|c|c|c|c|c|c|c|}
\hline \multirow{2}{*}{ Model Selected } & \multirow{2}{*}{ Covariate (s) } & \multirow{2}{*}{ Model Form } & \multicolumn{2}{|c|}{ Parameter Estimates } & \multicolumn{2}{|c|}{ Standard Error } \\
\hline & & & $a$ & $b$ & $a$ & $b$ \\
\hline \multicolumn{7}{|c|}{ Genus: Dipterocarpus } \\
\hline $\mathrm{D} 1$ & $\mathrm{DBH}$ & $\mathrm{AGB}=a \times \mathrm{DBH}^{b}$ & 0.03713 & 2.73813 & 0.00488 & 0.04310 \\
\hline D2 & $\mathrm{DBH}, \mathrm{H}$ & $\mathrm{AGB}=a \times\left(\mathrm{DBH}^{2} \mathrm{H}\right)^{b}$ & 290.370 & 1.03913 & 9.30399 & 0.01900 \\
\hline D3 & $\mathrm{DBH}, \mathrm{WD}$ & $\mathrm{AGB}=a \times\left(\mathrm{DBH}^{2} \mathrm{WD}\right)^{b}$ & 0.09387 & 1.31539 & 0.01047 & 0.02101 \\
\hline D4 & $\mathrm{DBH}, \mathrm{H}, \mathrm{WD}$ & $\mathrm{AGB}=a \times\left(\mathrm{DBH}^{2} \mathrm{HWD}\right)^{b}$ & 0.45812 & 1.00673 & 0.04729 & 0.01707 \\
\hline \multicolumn{7}{|l|}{ Genus: Shorea } \\
\hline S1 & $\mathrm{DBH}$ & $\mathrm{AGB}=a \times \mathrm{DBH}^{b}$ & 0.07483 & 2.54496 & 0.02897 & 0.13722 \\
\hline $\mathrm{S} 2$ & $\mathrm{DBH}, \mathrm{H}$ & $\mathrm{AGB}=a \times\left(\mathrm{DBH}^{2} \mathrm{H}\right)^{b}$ & 325.264 & 0.95220 & 24.2081 & 0.04909 \\
\hline S3 & $\mathrm{DBH}, \mathrm{WD}$ & $\mathrm{AGB}=a \times\left(\mathrm{DBH}^{2} \mathrm{WD}\right)^{b}$ & 0.19114 & 1.16390 & 0.06181 & 0.06166 \\
\hline S4 & $\mathrm{DBH}, \mathrm{H}, \mathrm{WD}$ & $\mathrm{AGB}=a \times\left(\mathrm{DBH}^{2} \mathrm{HWD}\right)^{b}$ & 0.69838 & 0.92173 & 0.13807 & 0.03772 \\
\hline
\end{tabular}

However, as increasing the number of input variables from one (DBH) to three (DBH, $\mathrm{H}$, and WD) did not improve model fit for either genus, the following simple AGB models with DBH as the only independent variable were selected for Dipterocarpus and Shorea, respectively.

$$
\begin{gathered}
\text { Dipterocarpus : } \mathrm{AGB}=0.03713 \times \mathrm{DBH}^{2.73813} \\
\text { Shorea }: \mathrm{AGB}=0.07483 \times \mathrm{DBH}^{2.54496}
\end{gathered}
$$

When differences between observed and predicted AGB values were compared over tree size, no evidence of lack of fit was found. The models predicted AGB across tree sizes well for both Dipterocarpus and Shorea. The plots of fitted and weighted residuals of the selected models showed no trend or patterns for both genera (Figure 5). 

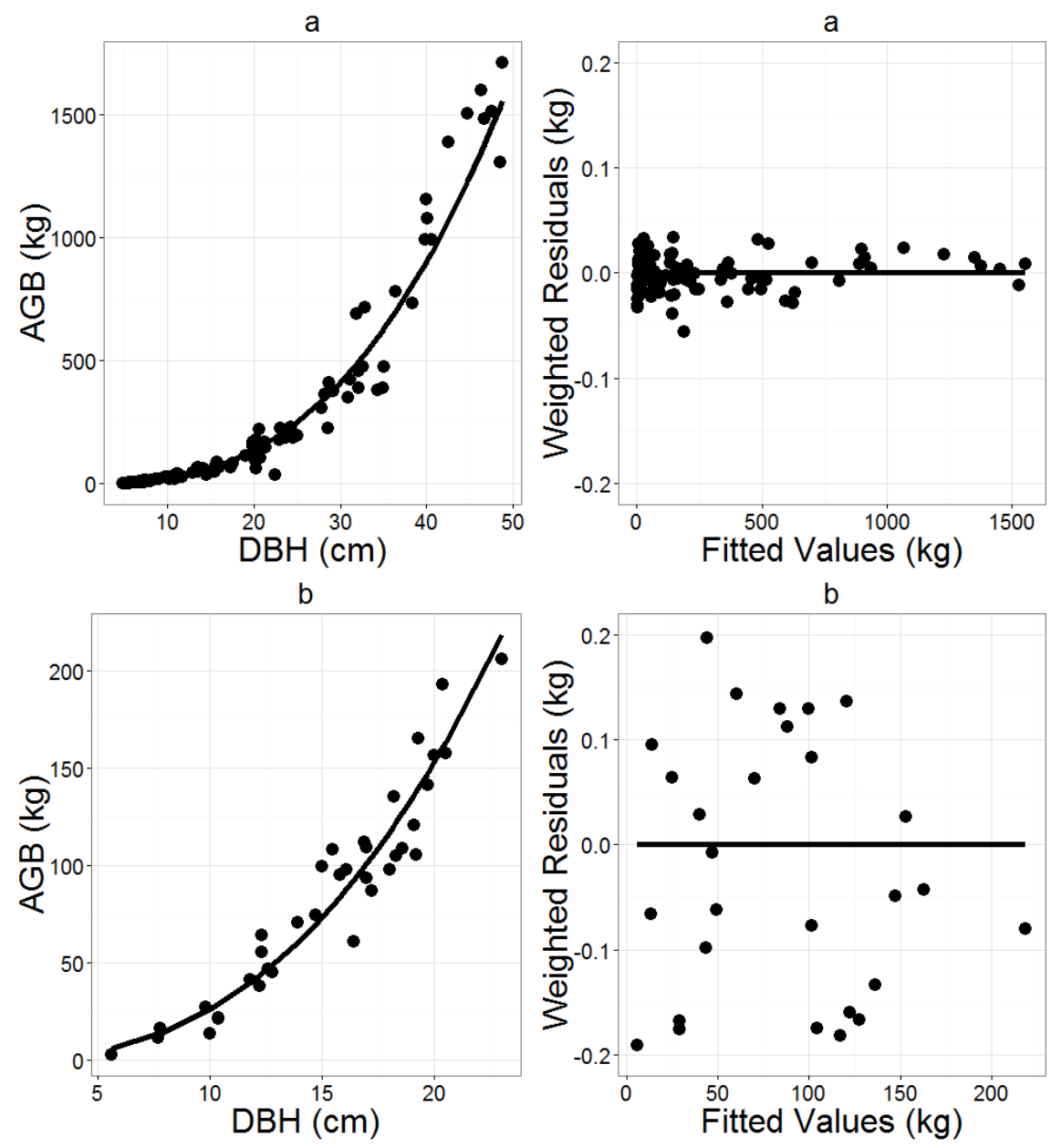

Figure 5. Plots of fitted values vs. DBH (left) and fitted values vs. weighted residuals (right) of the selected model AGB $=a \times \mathrm{DBH}^{b}$ for two main genera: (a) Dipterocarpus (the entire dataset, $n=94$ trees), and (b) for Shorea (the entire dataset, $n=36$ trees).

\subsection{Equation Validation and Comparison}

\section{Mixed-species equations:}

Cross-validation was employed for the four selected mixed-species equations (M1-M4) and compared to the mixed-species equations for dipterocarp of Indonesia (Equations (13) and (14)) and pantropic forests (Equations (9)-(12)). Averaged validation statistics over the 200 realizations for mixed-species equations are presented in Table 7 for all three DBH classes.

The MAPE of the four selected equations (M1-M4) ranged from $24.0 \%$ to $25.7 \%$, while the range was from $36.6 \%$ to $81.9 \%$ for the pantropic equations. Compared to the generic pantropic equations, the equations regionally specific to Vietnam reduced MAPE by $13 \%$ to $56 \%$ for dipterocarp forests in Vietnam.

The AGB estimates obtained from the four selected mixed-species equations (M1-M4), closely match the observed values of the validation dataset (Figure 6) and produced the lowest values for percent bias, RMSPE, and MAPE in all three DBH classes (Table 7). The pantropic equations and the equations developed for dipterocarp forests of Indonesia (Equations (9)-(14)) all overestimated AGB for the validation dataset (Figure 6) and had significantly higher percent bias, RMSPE, and MAPE than produced by equations M1-M4 in all three DBH classes (Table 7). 
Table 7. Percent bias, RMSPE, and MAPE for the selected mixed-species models, mixed-species models for dipterocarp forest of Indonesia, and pantropical models for mixed-species by covariate (s).

\begin{tabular}{|c|c|c|c|c|c|}
\hline Covariate (s) & Model & DBH Class (cm) & Percent Bias & RMSPE & MAPE \\
\hline \multirow{16}{*}{$\mathrm{DBH}$} & \multirow{4}{*}{$\begin{array}{l}\text { Brown (1997) [12] } \\
\text { Equation (9) }\end{array}$} & $<15$ & -86.5 & 106.7 & 86.5 \\
\hline & & $15-30$ & -74.0 & 80.9 & 74.0 \\
\hline & & $>30$ & -79.0 & 92.7 & 79.0 \\
\hline & & All & -80.9 & 101.5 & 80.9 \\
\hline & \multirow{4}{*}{$\begin{array}{l}\text { IPCC (2003) [18] } \\
\text { Equation (10) }\end{array}$} & $<15$ & -86.8 & 106.4 & 86.8 \\
\hline & & $15-30$ & -76.2 & 83.1 & 76.2 \\
\hline & & $>30$ & -79.2 & 93.0 & 79.2 \\
\hline & & All & -81.9 & 102.0 & 81.9 \\
\hline & \multirow{4}{*}{$\begin{array}{l}\text { Basuki et al. I (2009) [13] } \\
\text { Equation (13) }\end{array}$} & $<15$ & -132.2 & 163.5 & 132.2 \\
\hline & & $15-30$ & -64.6 & 72.0 & 64.6 \\
\hline & & $>30$ & -37.7 & 57.6 & 47.8 \\
\hline & & All & -92.3 & 126.2 & 94.2 \\
\hline & \multirow{4}{*}{ M1 } & $<15$ & 2.5 & 32.0 & 24.3 \\
\hline & & $15-30$ & -3.4 & 21.9 & 19.4 \\
\hline & & $>30$ & -17.2 & 43.7 & 38.1 \\
\hline & & All & -3.1 & 34.6 & 25.2 \\
\hline \multirow{4}{*}{$\mathrm{DBH}, \mathrm{H}$} & \multirow{4}{*}{ M2 } & $<15$ & 0.1 & 31.6 & 24.2 \\
\hline & & $15-30$ & -2.1 & 19.9 & 16.9 \\
\hline & & $>30$ & -18.0 & 41.8 & 36.2 \\
\hline & & All & -3.9 & 33.5 & 24.0 \\
\hline \multirow{12}{*}{ DBH, WD } & \multirow{4}{*}{$\begin{array}{l}\text { Chave et al. (2005) [16] } \\
\text { Equation (11) }\end{array}$} & $<15$ & -97.2 & 117.3 & 97.3 \\
\hline & & $15-30$ & -73.8 & 83.8 & 73.8 \\
\hline & & $>30$ & -46.5 & 69.7 & 56.0 \\
\hline & & All & -79.2 & 105.0 & 81.1 \\
\hline & \multirow{4}{*}{$\begin{array}{l}\text { Basuki et al. II (2009) [13] } \\
\text { Equation (14) }\end{array}$} & $<15$ & -139.2 & 164.2 & 139.2 \\
\hline & & $15-30$ & -90.3 & 99.1 & 90.3 \\
\hline & & $>30$ & -56.4 & 76.4 & 61.5 \\
\hline & & All & -107.6 & 136.9 & 108.7 \\
\hline & \multirow{4}{*}{ M3 } & $<15$ & 2.8 & 28.4 & 21.1 \\
\hline & & $15-30$ & -8.3 & 27.4 & 23.6 \\
\hline & & $>30$ & -15.5 & 47.2 & 39.6 \\
\hline & & All & -4.1 & 36.5 & 25.7 \\
\hline \multirow{8}{*}{$\mathrm{DBH}, \mathrm{H}, \mathrm{WD}$} & \multirow{4}{*}{$\begin{array}{l}\text { Chave et al. (2014) [17] } \\
\text { Equation (12) }\end{array}$} & $<15$ & -27.1 & 44.5 & 33.0 \\
\hline & & $15-30$ & -30.9 & 41.8 & 33.9 \\
\hline & & $>30$ & -42.9 & 60.3 & 48.2 \\
\hline & & All & -31.2 & 53.5 & 36.6 \\
\hline & \multirow{4}{*}{ M4 } & $<15$ & 0.1 & 26.5 & 20.6 \\
\hline & & $15-30$ & -7.4 & 23.7 & 20.2 \\
\hline & & $>30$ & -16.6 & 46.1 & 38.5 \\
\hline & & All & -5.2 & 34.7 & 24.2 \\
\hline
\end{tabular}



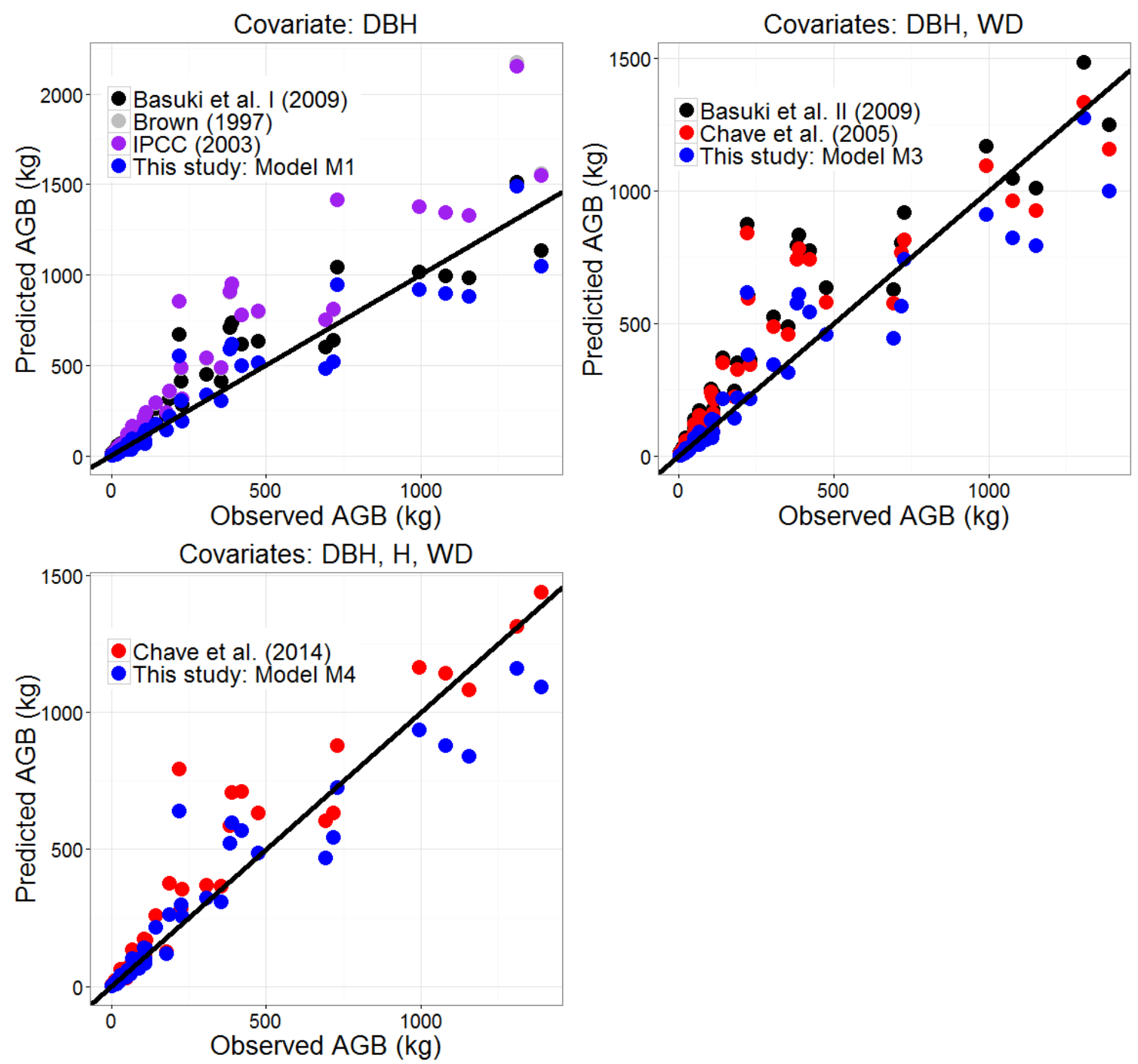

Figure 6. Observed vs. predicted AGB obtained from the mixed-species equations developed in this study, pantropical equations, and equations for dipterocarp forest of Indonesia.

Genus-level equations:

The selected genus-level models for Dipterocarpus and Shorea (D1 and S1, respectively) were cross-validated and compared to those of Basuki et al. [13] that were developed for the same genera, though located in Indonesia (Equations (15) and (16), respectively). Predictions from Equations (D1), (S1) and (16) closely matched the random validation data, with low values for percent bias, RMSPE, and MAPE in all three DBH classes (Table 8, Figure 7). The validation statistics (percent bias, RMSPE, and MAPE) were higher for Equation 15, Basuki et al.'s Dipterocarpus equation (overall bias $-50.9 \%$ vs. $7.9 \%$ ), but the biases were similar for Shorea (10.4\% vs. $9.6 \%)$. 
a

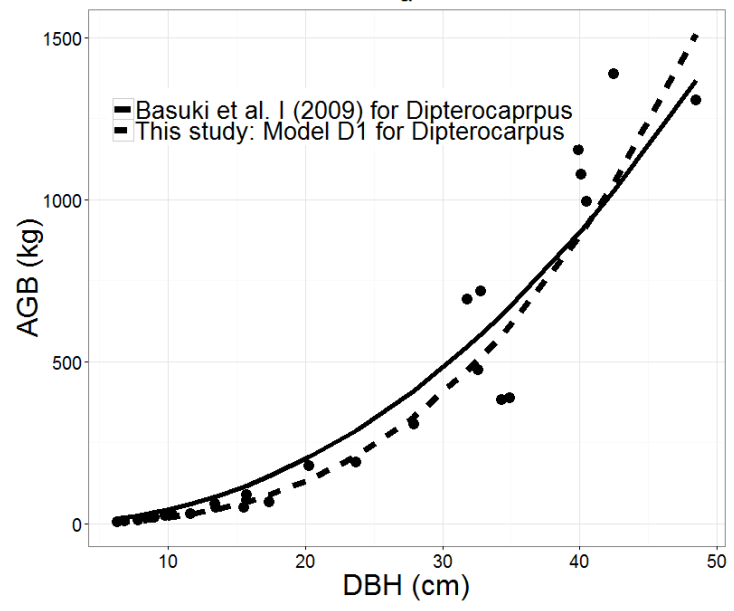

b

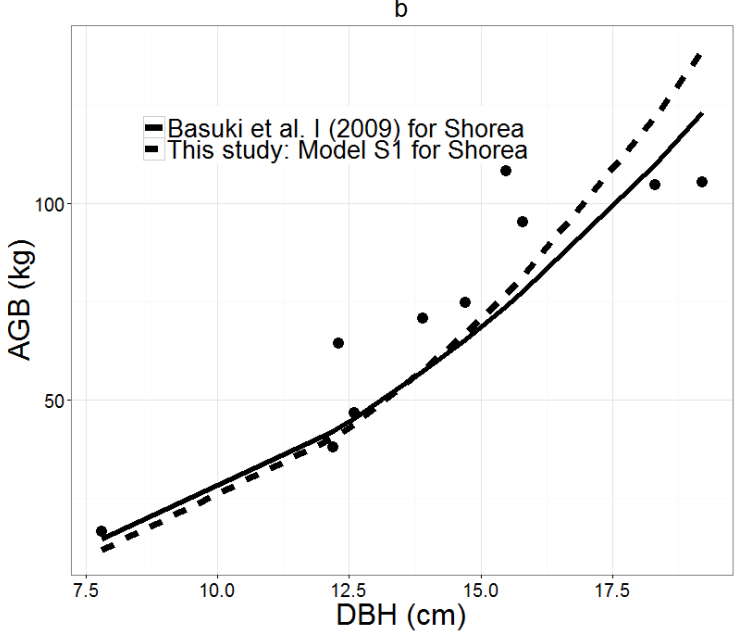

Figure 7. Predictions of AGB by the DBH-based genus-specific models developed in this study and those developed for dipterocarp forest of Indonesia for (a) Dipterocarpus and (b) Shorea genera.

Table 8. Percent bias, RMSPE, and MAPE for the selected genus-specific models and genus-specific equations for dipterocarp forest of Indonesia.

\begin{tabular}{|c|c|c|c|c|c|c|}
\hline Genus & Covariate (s) & Equation & DBH Class (cm) & Percent Bias & RMSPE & MAPE \\
\hline \multirow{8}{*}{ Dipterocarpus } & \multirow{8}{*}{$\mathrm{DBH}$} & \multirow{4}{*}{$\begin{array}{l}\text { Basuki et al. I (2009) [13] } \\
\text { Equation (15) }\end{array}$} & $<15$ & -91.7 & 94.9 & 91.7 \\
\hline & & & $15-30$ & -61.8 & 61.5 & 61.4 \\
\hline & & & $>30$ & -5.7 & 30.5 & 27.6 \\
\hline & & & All & -50.9 & 70.6 & 59.7 \\
\hline & & \multirow{4}{*}{ D1 } & $<15$ & 18.4 & 19.5 & 18.4 \\
\hline & & & $15-30$ & -5.2 & 17.2 & 17.2 \\
\hline & & & $>30$ & 0.2 & 28.2 & 25.9 \\
\hline & & & All & 7.9 & 24.2 & 21.8 \\
\hline \multirow{8}{*}{ Shorea } & \multirow{8}{*}{$\mathrm{DBH}$} & \multirow{4}{*}{$\begin{array}{l}\text { Basuki et al. (2009) [13] } \\
\text { Equation (16) }\end{array}$} & $<15$ & 13.3 & 15.7 & 15.8 \\
\hline & & & $15-30$ & 6.8 & 19.4 & 17.9 \\
\hline & & & $>30$ & - & - & - \\
\hline & & & All & 10.4 & 18.0 & 16.7 \\
\hline & & \multirow[t]{4}{*}{ S1 } & $<15$ & 16.8 & 18.2 & 18.4 \\
\hline & & & $15-30$ & -1.2 & 23.5 & 22.7 \\
\hline & & & $>30$ & - & - & - \\
\hline & & & All & 9.6 & 21.2 & 19.9 \\
\hline
\end{tabular}

\section{Discussion}

We obtained a large dataset consisting of 222 destructively sampled trees from two ecoregions, the original location of dipterocarp forests, to develop biomass equations for the tropical dipterocarp forests of Vietnam. Since the selection of sample trees was based on the diameter distribution, the number of trees sampled in the larger diameter class is still small. Thus, having additional sample trees in the larger diameter classes would further improve the reliability of these equations. Additionally, biomass allometry is affected by stand structure, developmental stage and other stand attributes. Thus, having such attributes in the biomass equations might further improve the predictive ability of such equations. However, this could complicate the model forms.

\subsection{Input Variables for AGB Mixed-Species Equations for Dipterocarp Forests}

Aboveground tree biomass is known to be affected by tree diameter, height, and wood density; diameter and height yield volume with wood density act as a scaling factor for biomass. The mixed-species equations available in this region have used different explanatory variables to 
estimate aboveground biomass e.g., $[12,13,16,17,19]$. For modeling AGB in mixed-species dipterocarp forests, we found that an equation with $\mathrm{DBH}$ as the only covariate performed poorly (highest AIC) when compared to equations that also incorporated $\mathrm{H}, \mathrm{WD}$, or both $\mathrm{H}$ and WD variables. Furthermore, the mixed-species equation developed in this study that incorporated all three variables resulted in the lowest uncertainty and lowest AIC. This could be due to the fact that at the mixed-species level, the wood density component helps in adjusting for the differences in allometric relationship between $\mathrm{DBH}$ and $\mathrm{H}$ among species. Thus, the best option for mixed-species was the AGB equation with three variables, $\mathrm{DBH}, \mathrm{H}$, and $\mathrm{WD}$, in the form of M4. We would like to point out the use of height in fitting biomass equations. Commonly, the height measured after felling the sample trees is used in model development but the standing tree heights are used in applying these equations. This discrepancy in the variable used in model fitting and application can result in biased estimate of the AGB and the magnitude of bias depends on the sign and magnitude of bias in height measurement as well as the model form and coefficients.

\subsection{Equations at the Mixed-Species Level in the Dipterocarp Forests of Southeast Asia}

While generic equations for estimating AGB in tropical forests exist $[12,16,17,19]$, the dipterocarp forest is a specific forest type dominated by the Dipterocarpaceae plant family and has specific site conditions that differ from those of other forest types. Therefore, the application of pantropic equations for dipterocarp forests must be evaluated.

The mixed-species pantropic equations of Brown [12], IPCC [19], and Chave et al. [16,17] for tropical forests all overestimate the AGB of mixed-species dipterocarp forests in Vietnam (Figure 6). Based on the Vietnam mixed-species validation dataset, the pantropic equations produced higher percent bias, RMSPE, and MAPE than the equations developed in this study for mixed-species dipterocarp forests of Vietnam (Table 7).

Basuki et al.'s [13] equations for mixed-species dipterocarp forests in Indonesia (Equations (13) and (14)) also overestimated the AGB of mixed-species dipterocarp forests in Vietnam (Figure 6). These mixed-species equations developed based on dipterocarp forests of Indonesia resulted in substantially higher MAPE ( $94 \%$ to $108 \%$ ) than the selected mixed-species equations developed in this study ( $24 \%$ to $26 \%$ ). The substantial differences in performance between these sets of equations can partially be explained by the different species used in the studies. There was no overlap in species used in equation development between the 26 species reported by Basuki et al. [14] and the 26 species from this study, despite the fact that they include some of the same main families and genera, such as Dipterocarpus and Shorea. Our evaluation shows that while equations developed for specific ecoregions (e.g., $\mathrm{CH}$ or SE) do not increase the reliability and accuracy of the AGB estimates when applied at the mixed-species level of the dipterocarps, regionally specific equations (e.g., Vietnam) offer considerable improvement over pantropic equations or equations developed for other regions (e.g., Indonesia). This finding is supported by the work of Basuki et al. [14], Nelson et al. (1999) [31], and Cairns et al. (2003) [32], which indicated that site-specific equations improve the accuracy of biomass estimates [33].

\subsection{Equations at the Genus Level in the Dipterocarp Forests of Southeast Asia}

The results demonstrate that the allometric equations developed at the genus-level in different regions (e.g., Vietnam vs. Indonesia) were not significantly different in accuracy (Figure 7 and Table 8). As a subset of the species list for mixed-species equations, the species list for the Dipterocarpus and Shorea genera used in genus-level equation development by Basuki et al. [13] differed from that of this study (Table 1). However, the prediction of AGB values from the genus equations of Basuki et al. [13] (Equations 16 for Shorea genus) and from this study (S1) were not substantially different. This could be because the species in the same genus have similar of tree foliage structure, stem form, and in particular the WD, compared to trees in a different genus (Figure 3). Such differences are not accounted for in the generic equations. These evaluations support the application of common equations for each plant genus of the dipterocarp forests throughout Southeast Asia. Future research using additional data would further validate our findings. 


\section{Conclusions}

All variables of diameter at breast height $(\mathrm{DBH})$, height $(\mathrm{H})$, and wood density $(\mathrm{WD})$ affected aboveground biomass (AGB). Increasing number of input variables from one to three reduced the uncertainty of the estimates. However, from an application perspective, a simpler model might be preferred as obtaining the wood density variable is very difficult. In general, for tropical forests with a large number of tree species, using the mixed-species model with multi-tree input variables was appropriate to improve the accuracy of the AGB estimates.

The predicted values from generic equations overestimated AGB in mixed-species dipterocarp forests. Because the dipterocarp forest is a specific forest type, the equations specific to different regions of Southeast Asia are appropriate and increase the reliability and accuracy of the AGB estimates.

The power models with $\mathrm{DBH}$ as the only input variable for the Dipterocarpus and Shorea genera were developed and validated for application to the dipterocarps. We speculate that using genus-specific equations improve the reliability of the AGB estimates in the dipterocarp forests over generic mixed-species equations. There were no substantial differences in accuracy among the developed equations for the same genus in different regions or countries. Therefore, it seems reasonable to develop and apply the common equations for each genus of the dipterocarps throughout Southeast Asia.

Acknowledgments: This work was undertaken in 2014, with the support of the UN-REDD+ Vietnam Phase II Program and built on an extensive field measurement campaign supported by the UN-REDD+ Vietnam Phase I Program in 2012 and 2013, and a research was carried out in 2010-2013 in the Central Highlands by Tay Nguyen University with funding from Ministry of Education and Training. Four institutions collaborated on the field work and analysis: Forest Inventory and Planning Institute, Vietnamese Academy of Forest Sciences, Vietnam National University of Forestry and Tay Nguyen University, with technical assistance from FAO. The authors also would like to acknowledge technical support provided by Gael Sola (FAO). We acknowledge Caryn Davis for her edits on an earlier manuscript.

Author Contributions: Bao Huy, Nguyen Dinh Hung, Phung Van Khoa, Vu Tan Phuong collected data set and analyzed the raw data; Bao Huy, Hailemariam Temesgen, Krishna P. Poudel developed methodology and analyzed data for equation development and validation; Bao Huy, Krishna P. Poudel, Karin Kralicek, Hailemariam Temesgen, Nguyen Dinh Hung, Phung Van Khoa and Vu Tan Phuong wrote the paper.

Conflicts of Interest: The authors declare no conflict of interest.

\section{References}

1. Measurement, Reporting \& Verification (MRV) Framework Document. Available online: http://theredddesk. org/resources/measurement-reporting-and-verification-framework-document (accessed on 17 August 2016).

2. UNFCCC (United Nations Framework Convention on Climate Change). Report of the Conference of the Parties on its Thirteenth Session; Proceedings of UNFCCC: Bonn, Germany, 2008.

3. Appanah, S. Management of Natural Forests. In A Review of Dipterocarp: Taxonomy, Ecology and Silviculture; Appanah, S., Turnbull, J.M., Eds.; Center for International Forestry Research (CIFOR): Bogor, Indonesia, 1998; pp. 130-149.

4. Maury-Lechon, G.; Curtet, L. Biogeography and Evolutionary Systematics of Dipterocarpaceae. In A Review of Dipterocarp: Taxonomy, Ecology and Silviculture; Appanah, S., Turnbull, J.M., Eds.; Center for International Forestry Research (CIFOR): Bogor, Indonesia, 1998; pp. 5-44.

5. Huy, B. Part B1: Equations for Biomass of Aboveground Trees, Branches and Leaves Biomass in Evergreen Broadleaved Forests, and for Aboveground Biomass of Six Tree Families in Evergreen and Deciduous Forests. In Allometric Equations at National Scale for Estimating Tree and Forest Biomass in Vietnam; Sola, G., Inoguchi, A., Garcia-Perez, J., Donegan, E., Birigazzi, L., Henry, M., Eds.; UN-REDD Programme: Ha Noi, Vietnam, 2014.

6. Jenkins, J.C.; Chojnacky, D.C.; Heath, L.S.; Birdsey, R.A. Comprehensive Database of Diameter-based Biomass Regressions for North American Tree Species; General Technical Report NE-319; USDA Forest Service: Newtown Square, PA, USA, 2004; p. 45.

7. Jenkins, J.C.; Chojnacky, D.C.; Heath, L.S.; Birdsey, R.A. National-scale biomass estimators for USA tree species. J. For. Sci. 2003, 49, 12-35. 
8. Sola, G.; Inoguchi, A.; Garcia-Perez, J.; Donegan, E.; Birigazzi, L.; Henry, M. Allometric Equations at National Scale for Tree Biomass Assessment in Vietnam, Context, methodology and summary of the results; UN-REDD Programme: Ha Noi, Vietnam, 2014.

9. Sola, G.; Inoguchi, A.; Phuong, V.T.; Huy, B.; Khoa, P.V.; Hung, N.D.; Xuan, N.V.; Henry, M. Allometric Equations at National Scale for Tree Biomass Assessment in Vietnam; UN-REDD Programme: Ha Noi, Vietnam, 2014.

10. Ter-Mikaelian, M.T.; Korzukhin, M.D. Biomass equations for sixty-five North American tree species. J. For. Ecol. Manag. 1997, 97, 1-24. [CrossRef]

11. Pearson, T.R.H.; Brown, S.; Birdsey, R.A. Measurement Guidelines for the Sequestration of Forest Carbon; General Technical Report NRS-18; USDA Forest Service: Newton Square, PA, USA, 2007.

12. Estimating Biomass and Biomass Change of Tropical Forests: A Primer. (FAO Forestry Paper-134). Available online: http:/ / www.fao.org/docrep/W4095E/w4095e00.htm\#Contents (accessed on 16 August 2016).

13. Basuki, T.M.; Van Lake, P.E.; Skidmore, A.K.; Hussin, Y.A. Allometric equations for estimating the above-ground biomass in the tropical lowland Dipterocarp forests. For. Ecol. Manag. 2009, 257, 1684-1694. [CrossRef]

14. Picard, N.; Rutishauser, E.; Ploton, P.; Ngomanda, A.; Henry, M. Should tree biomass allometry be restricted to power models? For. Ecol. Manag. 2015, 353, 156-163. [CrossRef]

15. Chambers, J.Q.; dos Santos, J.; Ribeiro, R.J.; Higuchi, N. Tree damage allometric relationship and above-ground net primary production in central Amazon forest. For. Ecol. Manag. 2001, 152, 73-84. [CrossRef]

16. Chave, J.; Andalo, C.; Brown, S.; Cairns, M.A.; Chambers, J.Q.; Eamus, D.; Folster, H.; Fromard, F.; Higuchi, N.; Kira, T.; et al. Tree allometry and improved estimation of carbon stocks and balance in tropical forests. Oecologia 2005, 145, 87-99. [CrossRef] [PubMed]

17. Chave, J.; Mechain, M.R.; Burquez, A.; Chidumayo, E.; Colgan, M.S.; Delitti, W.B.C.; Duque, A.; Eid, T.; Fearnside, P.M.; Goodman, R.C.; et al. Improved allometric models to estimate the aboveground biomass of tropical trees. Glob. Change Biol. 2014, 20, 3177-3190. [CrossRef] [PubMed]

18. IPCC National Greenhouse Gas Inventories Programme. Good Practice Guidance for Land Use, Land-Use Change and Forestry; IPCC: Hayama, Japan, 2003; p. 295.

19. National Greenhouse Gas Inventories Programme. IPCC Guidelines for National Greenhouse Gas Inventories; IGES: Hayama, Kanagawa, Japan, 2006.

20. Keller, M.; Palace, M.; Hurtt, G. Biomass estimation in the Tapajos National Forest. Brazil examination of sampling and allometric uncertainties. For. Ecol. Manag. 2001, 154, 371-382. [CrossRef]

21. Ketterings, Q.M.; Coe, R.; van Noordwijk, M.; Ambagau, Y.; Palm, C.A. Reducing uncertainty in the use of allometric biomass equations for predicting above ground tree biomass in mixed secondary forests. For. Ecol. Manag. 2001, 146, 199-209. [CrossRef]

22. Huy, B.; Poudel, K.P.; Temegen, H. Aboveground biomass equations for evergreen broadleaf forests in South Central Coastal of Vietnam: Selection of eco-regional or pantropical models. For. Ecol. Manag. 2016, 376, 276-283. [CrossRef]

23. Hijmans, R.J.; Cameron, S.E.; Parra, J.L.; Jones, P.G.; Jarvis, A. Very high resolution interpolated climate surfaces for global land areas. Int. J. Climatol. 2005, 25, 1965-1978. [CrossRef]

24. Nachtergaele, F.O.; van Velthuizen, H.T.; Verelst, L.; Wiberg, D.; Batjes, N.H.; Dijkshoorn, J.A.; van Engelen, V.W.P.; Fischer, G.; Jones, A.; Montanarella, L.; et al. Harmonized World Soil Database (Version 1.2); FAO: Rome, Italy; IIASA: Laxenburg, Austria, 2012; p. 42.

25. Huy, B.; Ly, C.T.; Hung, V.; Nguyen, T.T.H.; Dinh, N.D. Define $\mathrm{CO}_{2}$ Absorbed in the Broad-Leaf Ever-Green Forests in the Central Highlands of Vietnam to Join the REDD+ Program; Technical Report. Ministry of Education and Training: Ha Noi, Vietnam, 2013.

26. Stewart, J.L.; Dunsdon, A.J.; Hellin, J.J.; Hughes, C.E. Wood Biomass Estimation of the Central American Dry Zone Species; Tropical Forestry Papers 26; Oxford Forestry Institute, Department of Plant Sciences, University of Oxford: Oxford, UK, 1992.

27. Nlme: Linear and nonlinear mixed effects models. Available online: http://CRAN.R-project.org/package= nlme. (accessed on 19 August 2016).

28. The R Project for Statistical Computing. Available online: https://www.R-project.org/ (accessed on 16 August 2016). 
29. Swanson, D.A.; Tayman, J.; Bryan, T.M. MAPE-R: A rescaled measure of accuracy for cross-sectional subnational population forecasts. J. Pop. Res. 2011, 28, 225-243. [CrossRef]

30. Temesgen, H.; Zhang, C.H.; Zhao, X.H. Modelling tree height-diameter relationships in multi-species and multi-layered forests: A large observational study from Northeast China. For. Ecol. Manag. 2014, 316, 78-89. [CrossRef]

31. Nelson, B.W.; Mesquita, R.; Pereira, J.L.G.; de Souza, S.G.A.; Batista, G.T.; Couta, L.B. Allometric regressions for improved estimate of secondary forest biomass in the Central Amazon. For. Ecol. Manag. 1999, 177, 149-167. [CrossRef]

32. Cairns, M.A.; Olmsted, I.; Granados, J.; Argaez, J. Composition and aboveground tree biomass of the dry semi-evergreen forest on Mexico's Yucatan Peninsula. For. Ecol. Manag. 2003, 186, 125-132. [CrossRef]

33. Temesgen, H.; Affleck, D.; Poudel, K.P.; Gray, A.; Sessions, J. A review of the challenges and opportunities in estimating above ground forest biomass using tree-level models. Scand. J. For. Res. 2015, 30, 326-335.

(C) 2016 by the authors; licensee MDPI, Basel, Switzerland. This article is an open access article distributed under the terms and conditions of the Creative Commons Attribution (CC-BY) license (http://creativecommons.org/licenses/by/4.0/). 